\author{
O.E. Baibara, M.V. Radchenko, V.A. Karpyna, A.I. Ievtushenko
}

\title{
A Review of the Some Aspects for the Development of ZnO Based Photocatalysts for a Variety of Applications
}

\author{
I.M. Frantsevych Institute for Problems of Material Science, National Academy of Sciences of Ukraine, Kyiv, Ukraine, \\ baibaraoleksii@gmail.com
}

\begin{abstract}
Today, one of the most important problems for humanity is the pollution of the environment with various organic pollutants that do not degrade under natural conditions that worsen the health of the people. Another problem is that well-known disinfectants become less effective because they develop resistance to bacteria and viruses. One way to solve these problems is to use heterogeneous photocatalysis to degrade harmful compounds and destroy bacteria, viruses, fungi, etc.

Among wide-bandgap semiconductors oxides (for existence, $\mathrm{TiO}_{2}, \mathrm{Cu}_{2} \mathrm{O}, \mathrm{Fe}_{3} \mathrm{O}_{4}, \mathrm{CeO}_{2}$, etc) suitable for photocatalytic applications, recent years special attention has been given to $\mathrm{ZnO}$ due to its unique features. $\mathrm{ZnO}$ in nanostructured form with an increased specific surface is a perspective for the development of effective photocatalytic materials for the organic pollutants decomposition and for designing materials with antimicrobial properties. In this review, various approaches for enhancing the effectiveness of photocatalytic processes of $\mathrm{ZnO}$ based materials for organic pollutants decomposition (including industrial dyes) are considered. Some antimicrobial properties of $\mathrm{ZnO}$ are also presented.
\end{abstract}

Keywords: zinc oxide, photocatalysis, photodegradation, nanostructures, antibacterial properties.

Received 24 June 2021; Accepted 25 August 2021.

\section{Introduction}

With the increase of industrial production and of the Earth's population, the ecological safety of mankind becomes relevant, which puts forward demands for the disposal of toxic products of industrial and agriculture production that pollutes water. It should be noted the constant problem of emissions of persistent organic pollutants (POP), which are not amenable to degradation in natural conditions and, thus, destroy the ecological sustainability of ecosystems [1, 2]. POP includes, for example, synthetic dyes, which account for almost half of the total industrial production of dyes. They are widely used in the textile, printing, leather, paint, paper, rubber, and plastic industries. Up to $15-20 \%$ of such dyes are lost in the process of synthesis and staining, getting in the form of pollutants into wastewater, leading to carcinogenic and mutagenic effects on living organisms [3]. Another well-known type of pollutant is pesticides - chemicals used to protect crops from pests [4].

On the other hand, infectious diseases remain one of the biggest problems in the world. Moreover, traditional environmental cleansing and antibacterial materials not only have side effects but also become less effective over time for many pollutants and bacteria [5].

$\mathrm{ZnO}$ is a direct band gap material with a $3.37 \mathrm{eV}$ band gap, has a high exciton binding energy $(60 \mathrm{meV})$, which determines its unique optical, chemical-sensor, semiconductor, conductive and piezoelectric properties [6]. $\mathrm{ZnO}$ also exhibits some photocatalytic activities, and thus considered a cost-effective, non-toxic, and promising material for the removal of POP with notable antibacterial and antiviral resistance [7].

Modern promising scientific research is aimed at studying the phenomenon of heterogeneous photocatalysis based on zinc oxide as an effective way of degradation organic pollutants and decontamination of pathogenic microorganisms (viruses, bacteria, fungal, 
mold, etc.) in the environment. The development of photocatalytic materials with antimicrobial activity is an effective and safe alternative to traditional disinfection methods, such as chlorination, ozonation or ultraviolet (UV) irradiation, which have a number of limitations on their use because some microorganisms are resistant to chlorine or other disinfectants [8-10].

$\mathrm{ZnO}$ nanoparticles exhibit attractive antimicrobial and photocatalytic properties due to the small particle size and increased reactivity of their surface. In addition, they are more biocompatible than other metal nanoparticles (NP), are easily synthesized and have high selectivity, enhanced cytotoxicity and are promising in modern antiviral, antimicrobial, biomedical and environmental fields $[8,11]$.

Despite active research on photocatalytic materials, a number of fundamental and applied questions remain in understanding the technology of obtaining nanostructured materials and its impact on the morphology, optical and photocatalytic properties.

The present work considers technological aspects of the synthesis of nanostructured photocatalytic materials based on $\mathrm{ZnO}$, as well as the ways to improve their photocatalytic, antibacterial and antiviral activities.

\section{The mechanism of photocatalysis and technological methods of synthesis of $\mathrm{ZnO}$ based nanostructures}

Photocatalysis is the activity occurring when a light source interacts with the surface of semiconductor materials, the so called photocatalysts. During this process, there must be at least two simultaneous reactions occurring, oxidation from photogenerated holes, and reduction from photogenerated electrons. Photocatalysts as like as catalysts participate in the chemical reaction without being consumed, changing only the rate of a chemical reaction that involves reacting species under a light excitation. The mechanisms of oxidation processes can be classified on the basis of homogeneous or heterogeneous photocatalysis. For homogeneous photocatalysis, Fenton's reagent is used, which is a mixture of hydrogen peroxide and $\mathrm{Fe}^{2+}$ salt to obtain hydroxyl radicals under the action of ultraviolet radiation at wavelengths over $300 \mathrm{~nm}$ [12]. On the contrary, heterogeneous photocatalysis is based on semiconductor oxides-photocatalysts [13]. Currently, studies using heterogeneous photocatalysis are developing very rapidly.

The process of heterogeneous photocatalytic oxidation of $\mathrm{ZnO}$ is shown in Fig. 1 [14]. There are several stages:

1. POP diffuse from the liquid phase to the $\mathrm{ZnO}$ surface.

2. Adsorption of POP on the $\mathrm{ZnO}$ surface.

3. Oxidation and reduction reactions in the adsorbed phase.

4. Desorption of products.

5. Remove products from the interface area.

The process of photocatalytic degradation of POP on catalyst nanoparticles occurs by the following mechanism [15]. Upon absorption by semiconductor nanoparticles (in this case $\mathrm{ZnO}$ ) of a quantum of light $h v$ with energy sufficient for the transition of an electron from the valence band to the conduction band, an electron-hole pair is formed:

$$
Z n O+h v \rightarrow e_{C B}^{-}+h_{V B}^{+}
$$

where $e_{C B}^{-}$and $h_{V B}^{+}$electron in the conduction band and the hole in the valence band, respectively. The charge migrating on the surface and interacting with the molecules of adsorbed water, forms radicals $\cdot \mathrm{OH}$, at the same time the free electron from the conduction band can interact with $\mathrm{O}_{2}$ molecules to form a superoxide anion radical of oxygen ${ }^{\prime} \mathrm{O}_{2}{ }^{-}$(Fig. 2). The corresponding reactions can be represented as follows:

$$
\begin{gathered}
h_{V B}^{+}+\mathrm{H}_{2} \mathrm{O} \rightarrow \mathrm{H}^{+}+{ }^{\bullet} \mathrm{OH} \\
e_{C B}^{-}+\mathrm{O}_{2} \rightarrow{ }^{\bullet} \mathrm{O}_{2}^{-}
\end{gathered}
$$

These radicals ${ }^{\circ} \mathrm{OH}$ and ${ }^{\circ} \mathrm{O}_{2}^{-}$belong to reactive oxygen species (ROS). Due to the presence of an unpaired electron at the external electron level, they have a significant reactivity, and can react with pollutant molecules to form other substances, thereby leading to their discoloration and degradation. Reactions (2) and (3) also prevent electron and hole recombination.

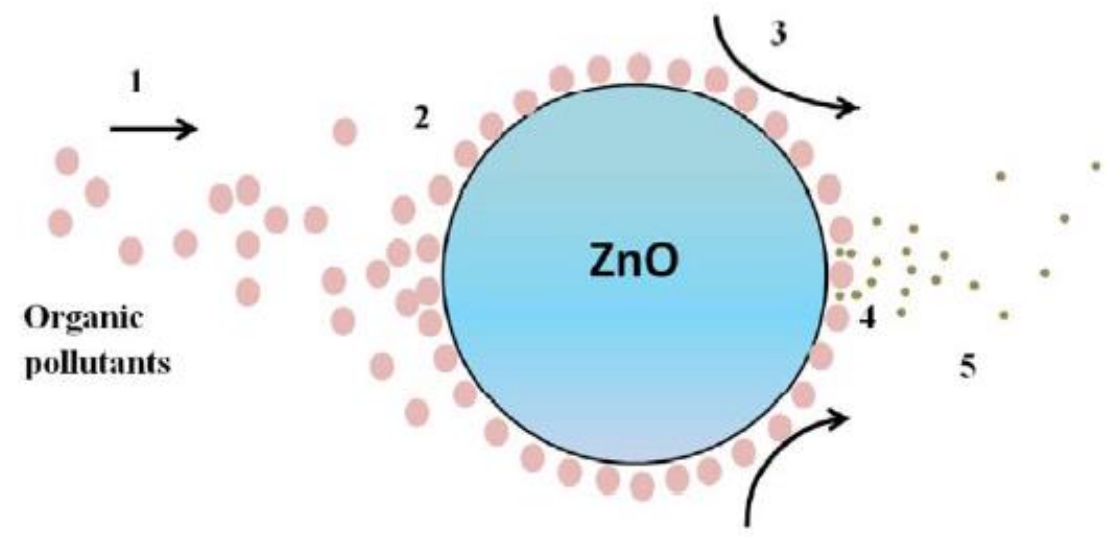

Fig. 1. Stages of heterogeneous photocatalytic oxidation [14]. 


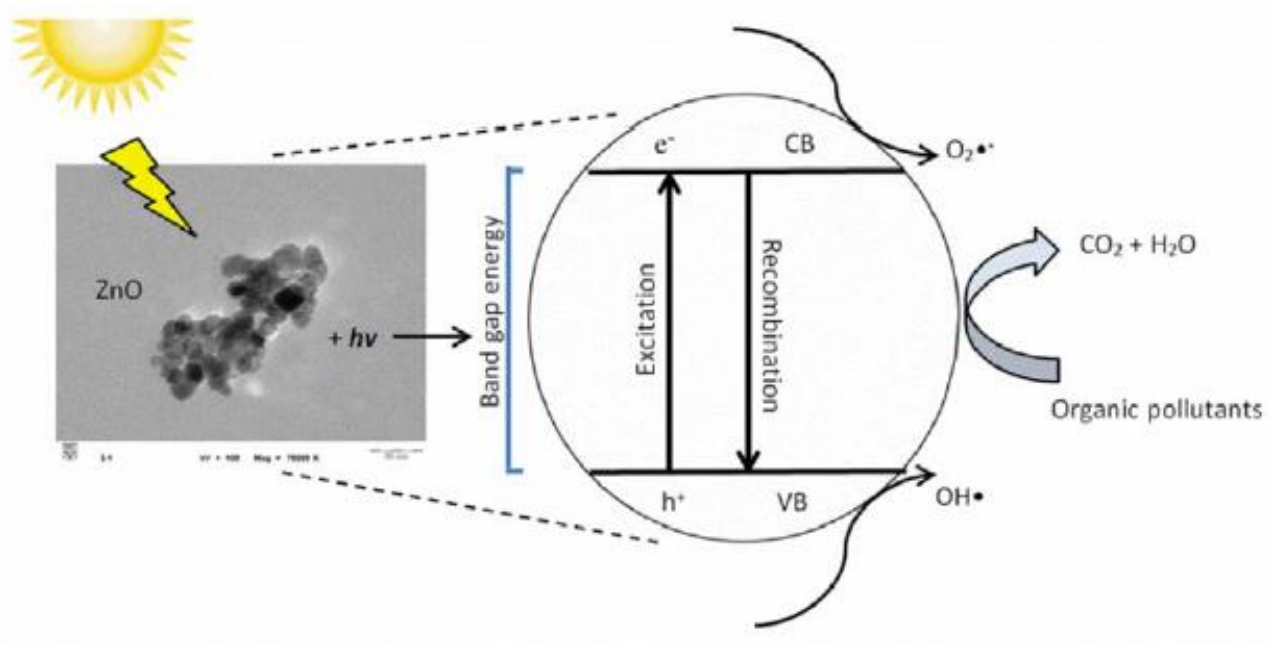

Fig. 2. Degradation of organic $\mathrm{ZnO}$ pollutants in the presence of sunlight [16].

The band gap energy and the separation of charge carriers in semiconductor oxides depend on the size of the nanoparticles, the crystalline phase and the texture. This means that the methods of synthesis $\mathrm{ZnO}$ nanostructures determine the efficiency of photocatalysis. There are various methods for the synthesis of $\mathrm{ZnO}$ nanostructures, among which the synthesis of $\mathrm{ZnO}$ nanomaterials based on liquid solutions is the simplest and least energy consuming. With this direction of synthesis, the morphology of nanostructures can be easily controlled by manipulating experimental factors such as the type of solvents, starting materials and reaction conditions [17]. This simple approach also offers better control over the size of nanostructures. Methods based on liquid solutions for the synthesis of $\mathrm{ZnO}$ nanostructures include hydrothermal, sol-gel precipitation, microemulsion, solvothermal, electrochemical precipitation process, polyol, wet chemical method, flux methods and electrospinning [18-21].

Among these methods, sol-gel is the most attractive method for the synthesis of $\mathrm{ZnO}$ nanostructures with good homogeneity and optical properties due to low production costs, high reliability, good reproducibility, process simplicity, low process temperature, easy control of physical characteristics and nanoparticle morphology.

On the other hand, production methods from the vapor phase are also actively used to obtain nanostructured materials. They include thermal evaporation [22], pulsed laser deposition [23], physical vapor deposition [24], chemical vapor deposition [25], organometallic chemical deposition (MOCVD) [26], plasma-enhanced chemical deposition (PEMOCVD) [27] and molecular beam epitaxy [28]. These methods allow to control the mechanism of growth of $\mathrm{ZnO}$, manipulating the initial temperature of nucleation.

The choice of $\mathrm{ZnO}$-photocatalists synthesis method mainly determined by the possibility to obtain $\mathrm{ZnO}$ nanostructures with desired size and morphology to be used in selected photocatalytic applications. It should also consider the reproducibility of the process and cost of initial components.

\section{Methods for enhancing the photocatalytic activity of $\mathrm{ZnO}$ based nanostructures}

\subsection{Formation of a special morphology of $\mathrm{ZnO}$ nanoparticles}

One of the simplest methods to improve photocatalytic activity is to form the morphology of a nanostructure with a high specific surface area. This allows to increase the efficiency of the photocatalytic process and to enhance the restoration of the properties of the photocatalyst after use. $\mathrm{ZnO}$ nanostructures can be zero-dimensional (0D), one-dimensional (1D), twodimensional (2D) and three-dimensional (3D). Zerodimensional (OD) are arrays of quantum dots, onedimensional (1D) - elongated arrays, two-dimensional (2D) - planar arrays and three-dimensional (3D) - ordered structures. Figure 3 shows the morphology of zinc oxide nanostructures of different dimensions. 1D $\mathrm{ZnO}$ arrays include nanostrings, nanofibers, nanowires, nanotubes and nanoneedles. Examples of $\mathrm{ZnO}$ nanostructures in two-dimensional and three-dimensional arrays are nanosheets and nanoflowers, respectively.

The photoactivity of the photocatalyst is affected by the size of its specific surface area. The large specific surface area and polar faces with $2 \mathrm{D} \mathrm{ZnO}$ nanostructures make them excellent candidates for maximum photocatalytic effect. Also, the large specific surface area of $\mathrm{ZnO}$ allows to adsorb more pollutants on its active surface, which leads to the fact that more pollutants are attacked by hydroxyl radicals. The reaction that occurs on the surface increases the rate of degradation of pollutants forming non-toxic products. In [29], it was reported that 3D nanoflowers showed higher sensitivity to ethanol degradation compared to $1 \mathrm{D}$ and $2 \mathrm{D}$ nanostructures due to the fact that nanoflowers have higher surface-to-volume ratios compared to nanostructures of other dimensions. In another study [30], $\mathrm{ZnO}$ nanoflowers arrays were fabricated by 

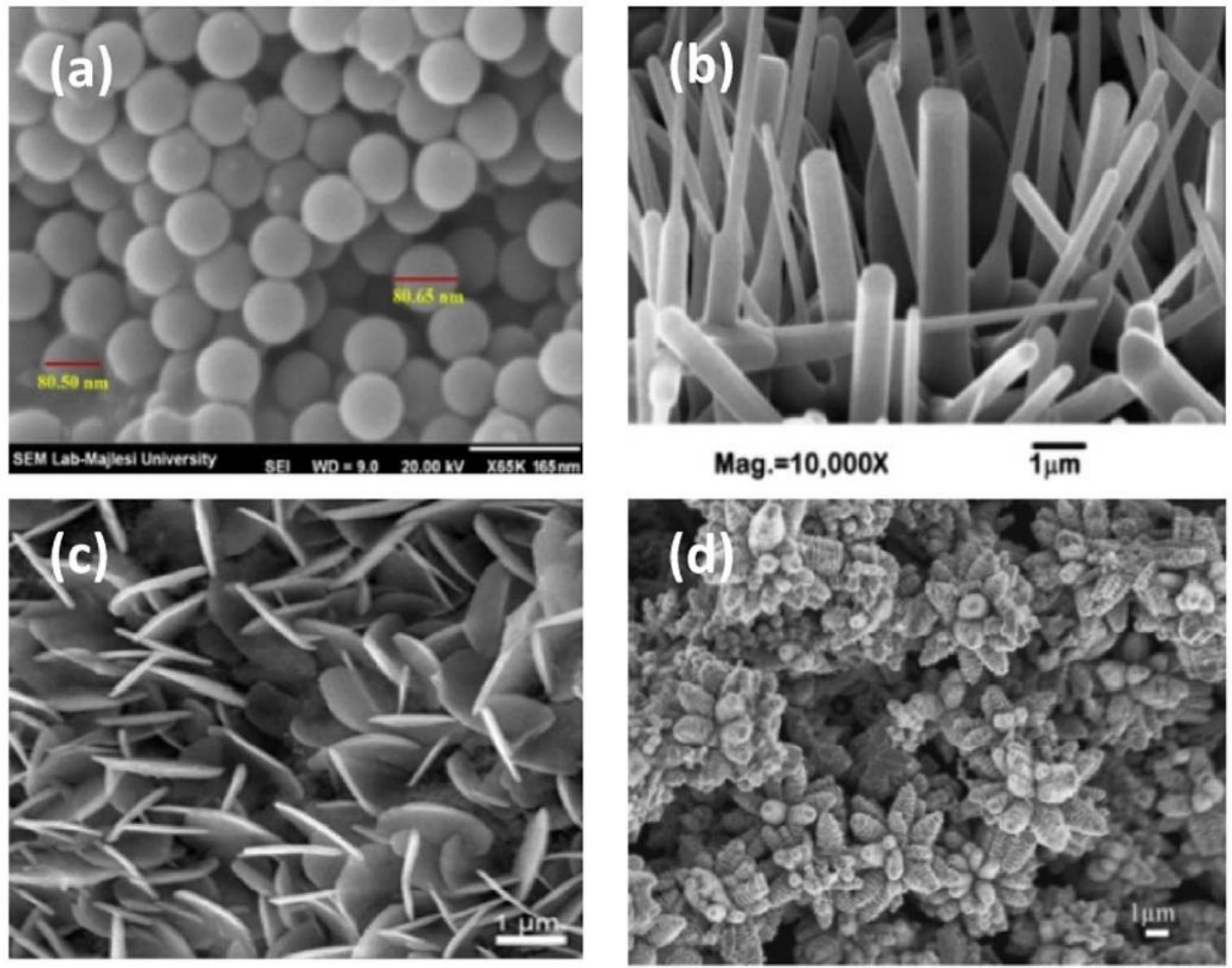

Fig. 3. Images of SEM nanostructures of zinc oxide of different dimensions [31-34]. $a-0 D ; b-1 D ; c-2 D ; d-3 D$.

incorporating $\mathrm{ZnO}$ nanowires into polystyrene spheres that were formed together with the $\mathrm{ZnO}$ layer. This approach combined the advantages of $1 \mathrm{D}$ and $3 \mathrm{D} \mathrm{ZnO}$ materials and helped to increase their specific surface area. This advanced approach has allowed 3D nanoflowers to become a promising material for creating photocatalysts for the effective destruction of dyes.

It can be concluded that increasing the surface area is a popular and effective method to increase the efficiency of photocatalysis, because more pollutants can be easily adsorbed and achieve a higher rate of photodegradation.

\subsection{Properties of doped $\mathrm{ZnO}$ nanostructures}

The photoactivity of the catalyst is due to its ability to generate electron-hole pairs. However, the main limitation of photocatalysts, which directly affects the efficiency of photocatalysis, is the high rate of recombination of photogenerated electron-hole pairs. In addition, the large band gap of such a photocatalyst limits the efficiency of sunlight. To overcome these shortcomings, many studies of $\mathrm{ZnO}$ doping with both metal atoms and non-metal atoms have been proposed and investigated. It should be noted that the photocatalytic activity of doped $\mathrm{ZnO}$ nanoparticles depends on various factors, such as phase purity, surface area, crystallite size, nature of the alloying substances and the production method [35]. Metals such as Al [3537], Ca [38, 39], Ag [40-42], Mn [43], Mg [44], Sr [45], $\mathrm{Fe}$ [46], $\mathrm{V}$ [47] and $\mathrm{Ce}$ [48] is now actively used as dopants to improve the photocatalytic activity of $\mathrm{ZnO}$. For example, in [49] it was shown that the sol-gel synthesized, undoped and doped $\mathrm{Ca}$ and $\mathrm{Al} / \mathrm{Ca} \mathrm{ZnO} \mathrm{NP}$ have a spherical shape with a crystallite size of $26.09 \mathrm{~nm}$, $25.23 \mathrm{~nm}$ and $24.5 \mathrm{~nm}$, respectively. Narrow discrete photoluminescence peaks are observed in doped $\mathrm{Al}$ and $\mathrm{Al} / \mathrm{Ca} \mathrm{ZnO} \mathrm{NP}$, which makes these materials also suitable for optical devices. All samples showed significant photocatalytic degradation. Among $\mathrm{ZnO}$ nanoparticles doped with calcium, the highest degradation efficiency was found $-89 \%$. On the other hand, in [50] it was shown that $\mathrm{Mg}^{2+}$ ions, which have a close ionic radius to $\mathrm{Zn}^{2+}$, are non-toxic and costeffective dopants to achieve better photocatalytic activity of $\mathrm{ZnO}$ nanoparticles. $\mathrm{Mg}$-doped $\mathrm{ZnO}$ nanocrystals were also investigated in [51, 52]. Samples of $\mathrm{ZnO}: \mathrm{Mg}$, with different magnesium content from 1 to $5 \%$, were synthesized by sol-gel method. The size of the NP ranged from $26.82 \mathrm{~nm}$ to $42.96 \mathrm{~nm}$ with increasing concentration of $\mathrm{Mg}$. The authors of the article found that a further increase in the proportion of $\mathrm{Mg}$ over $2 \%$ improves the photocatalytic activity of $\mathrm{ZnO} \mathrm{NP}$ in the process of photodegradation of rhodamine $\mathrm{B}$ under sunlight. The article states that the effective electron-hole separation is the main factor contributing to the increase of photocatalytic characteristics of $\mathrm{Mg}$-doped $\mathrm{ZnO} \mathrm{NP}$.

Doping of $\mathrm{ZnO}$ with rare earth metals, in particular $\mathrm{La}$, leads to the formation of more surface defects that prevent the recombination of photogenerated electron- 
hole pairs, resulting in improved photocatalytic activity [53]. Also, in [54], high-quality self-assembled $\mathrm{ZnO} \mathrm{NP}$ and La-doped ZnO NP were synthesized using the coprecipitation method. It was found that the structural, optical and photocatalytic properties largely depend on the inclusion of $\mathrm{La}^{3+}$ ions in the $\mathrm{ZnO}$ lattice. $\mathrm{ZnO}$ with morphology in the form of spherical nanocrystals showed increased photocatalytic activity than in $\mathrm{ZnO}$ with other morphology due to the small crystal size distribution, high specific surface area and a large number of oxygen vacancies. The authors of the article concluded that the obtained morphology with smaller particle size, high crystallinity and existing surface defects significantly enhances the photocatalytic activity of La-doped $\mathrm{ZnO} \mathrm{NP}$.

The influence of some doped metals on the photocatalytic activity of $\mathrm{ZnO}$ is shown in Table 1 .

The promising photocatalytic activity was also shown in $\mathrm{ZnO}-\mathrm{Au}$ nanocomposites [63]. These nanostructures were synthesized by coprecipitation of $\mathrm{ZnO}$ and $\mathrm{Au}$. $\mathrm{Au}$ nanoparticles were included in the $\mathrm{ZnO}$ matrix. As the concentration of $\mathrm{Au}$ increased, the morphology of the $\mathrm{ZnO}-\mathrm{Au}$ nanostructure was transformed from rods into flower-like structures with the shape of calendula (Fig. 4).

In these nanocomposites, an increase in light absorption in the visible region of the radiation spectrum
(450 - $650 \mathrm{~nm}$ ) was also observed due to the generation of surface plasmons in $\mathrm{Au}$ nanoparticles. The coincidence of the plasmon absorption of $\mathrm{Au}$ nanoparticles with the maximum of $550 \mathrm{~nm}$ used for irradiation of solar radiation was one of the reasons for the ultrafast photocatalytic degradation of Sulforhodamine B. The dye decomposition rate constant increased rapidly with increasing $\mathrm{Au}$ content. This increase in photocatalytic activity with increasing $\mathrm{Au}$ content was due to a combination of several favorable circumstances: (1) improved absorption of sunlight by surface plasmons in $\mathrm{Au}$, (2) a small expansion of the band gap in $\mathrm{ZnO}$, which reduced the recombination of electron-hole pairs. (3) an increase in the surface area of $\mathrm{ZnO} / \mathrm{Au}$ nanostructures compared to pure $\mathrm{ZnO}$, (4) the formation of a Schottky barrier at the boundary between $\mathrm{Au}$ and $\mathrm{ZnO}$.

A further direction to increase the efficiency of photocatalytic activity is the use of so-called hybrid composite materials. These include systems such as metal /metal oxide, ceramic or polymer, and systems where metallic or non-metallic nanoparticles are immobilized on the $\mathrm{ZnO}$ surface. The main purpose of such systems is the additional capture and subsequent transfer of photoexcited media to the surface of $\mathrm{ZnO}$, which increases its photocatalytic efficiency. Studies of hybrid materials have shown that the creation of hybrid

Table 1

The effect of different doped metals on the photocatalytic properties of $\mathrm{ZnO}$

\begin{tabular}{|c|l|c|}
\hline Type of doped metal & \multicolumn{1}{|c|}{ Reasons for increasing the photocatalytic activity } & References \\
\hline $\mathrm{Cu}$ & The synergistic effect of $\mathrm{Cu}$ and ZnO & {$[55]$} \\
\hline $\mathrm{Al}$ & Changed the crystal cell parameters & {$[56]$} \\
\hline $\mathrm{Fe}$ & $5 \%$ Fe doped ZnO NPs had smaller size, more uniform dispersion & {$[57]$} \\
\hline $\mathrm{Ga}$ & $\begin{array}{l}\text { Changed the morphology of ZnO, and increased the photoelectric } \\
\text { charge separation rate }\end{array}$ & {$[58]$} \\
\hline $\mathrm{Li}$ & The electron capture of lithium metal ions & {$[59]$} \\
\hline $\mathrm{K}$ & $\begin{array}{l}\text { Higher specific surface area, visible light absorption and lower optical } \\
\text { band gap }\end{array}$ & {$[60]$} \\
\hline $\mathrm{Nd}$ & Extended the life of photogenic charge & {$[61]$} \\
\hline $\mathrm{Eu}$ & $\begin{array}{l}\text { Acted as the electron scavenger to inhibit the photonic charge carrier } \\
\text { recombination }\end{array}$ & {$[62]$} \\
\hline
\end{tabular}
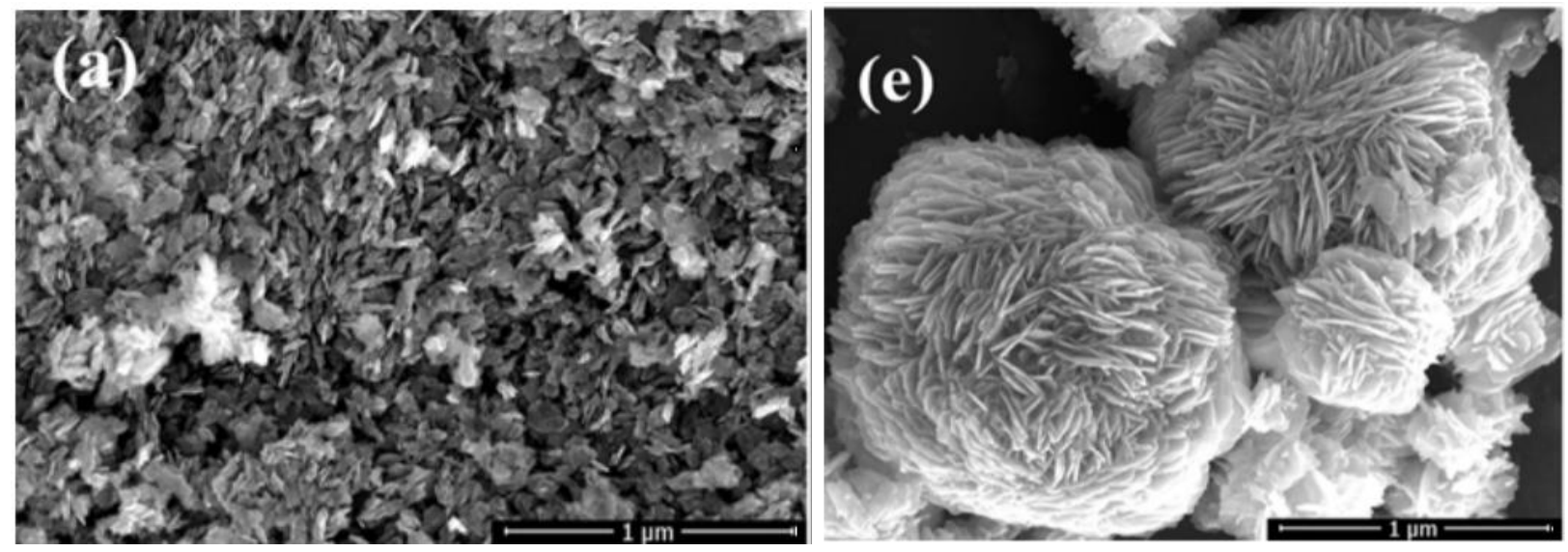

Fig. 4. Images of SEM nanostructures $\mathrm{ZnO}$ and $\mathrm{ZnO}-\mathrm{Au}$ [63]. a) - $\mathrm{ZnO}$; e) - $\mathrm{ZnO}: \mathrm{Au}$. 
heterostructures in the form of $\mathrm{ZnO} /$ metal oxide is an effective method of reducing the recombination of photoinduced electron-hole pairs. As an example, the hybrid $\mathrm{ZnO} / \mathrm{Fe}_{3} \mathrm{O}_{4}$ photocatalyst has aroused some interest due to the fact that $\mathrm{Fe}_{3} \mathrm{O}_{4}$ superparamagnetic nanoparticles have a promising adsorption capacity for pollutants along with optimal magnetic properties [64]. The combination of $\mathrm{Fe}_{3} \mathrm{O}_{4}$ with $\mathrm{ZnO}$ nanoparticles does not change the absorption edge of the system, but reduces its charge transfer resistance (Fig. 5). The hybrid $\mathrm{ZnO}$ photocatalyst grown on $\mathrm{Fe}_{3} \mathrm{O}_{4}$ nanoparticles is effective for the removal of toxic metal ions, organic contaminants, organic dyes (rhodamine $\mathrm{B}$, reactive black 5) and bacterial pathogens, as demonstrated in [65].

The improvement of photocatalytic properties of such a hybrid composite, according to the authors, is the result of the presence of $\mathrm{Fe}^{3+}$ ions, which slow down electron-hole recombination, which leads to greater catalytic efficiency of $\mathrm{ZnO} / \mathrm{Fe}_{3} \mathrm{O}_{4}$ nanocomposites [65].

Summarizing the above written, $\mathrm{ZnO}$ nanostructures are potential photocatalytic material for the degradation of POP under the action of sunlight. This is due to the lower cost of their production $(75 \%$ lower compared to $\mathrm{TiO}_{2}$ ), non-toxicity and the ability to absorb most of the solar spectrum, and, consequently, greater photocatalytic activity. It should also be noted that a significant amount of work is devoted to the photodegradation of POP in water, and direct photocatalytic interaction in the air is not as effective and requires additional research to increase it.

\section{Antibacterial and antiviral properties of $\mathrm{ZnO}$ based nanostructures}

$\mathrm{ZnO}$ nanoparticles exhibit attractive antibacterial and antiviral properties due to the small particle size and increased reactivity of the particle surface. In addition, they are more biocompatible compared to other metal nanoparticles, are easily synthesized and have high selectivity, enhanced cytotoxicity [66].

Physico-chemical interaction between the surface of biological components and the surface of the NP occurs due to kinetic and thermodynamic exchange between them [67]. It includes the interaction of biological membranes with NP and the interaction between the NP themselves (Fig. 6).

The scientific literature presents the following separate mechanisms of interaction with biomolecules: direct contact of $\mathrm{ZnO}$ with cell walls, which leads to the destruction of bacterial cell integrity [68], the release of antimicrobial ions, mainly $\mathrm{Zn}^{2+}$ [69], the formation of reactive oxygen species (ROS) [70], penetration of the NP into the middle of the cell, membrane dysfunction. In addition, ROS formed on the surface of the cell can also damage it [71].

Photocatalytic antibacterial action is described as a photoinduced oxidation process that can damage and

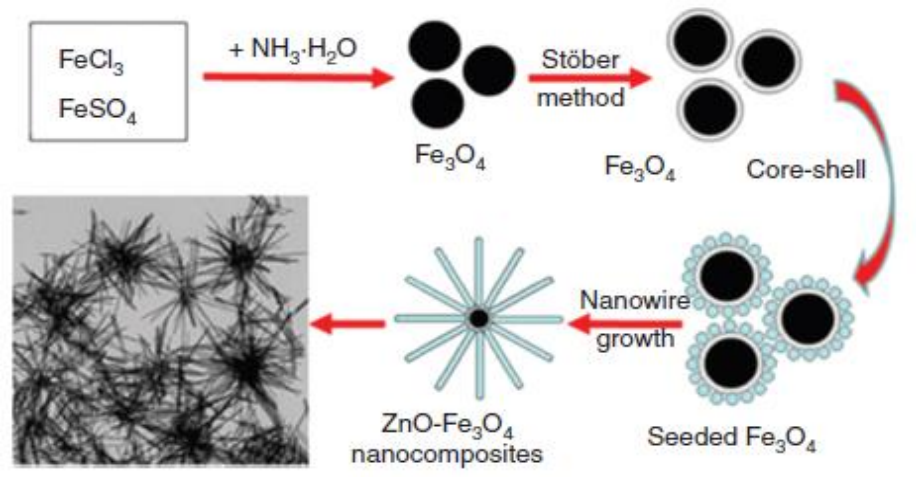

Fig. 5. Functional hierarchical nanocomposites based on $\mathrm{ZnO}$ nanowires and magnetic nanoparticles as highly active photocatalysts to be processed [65].
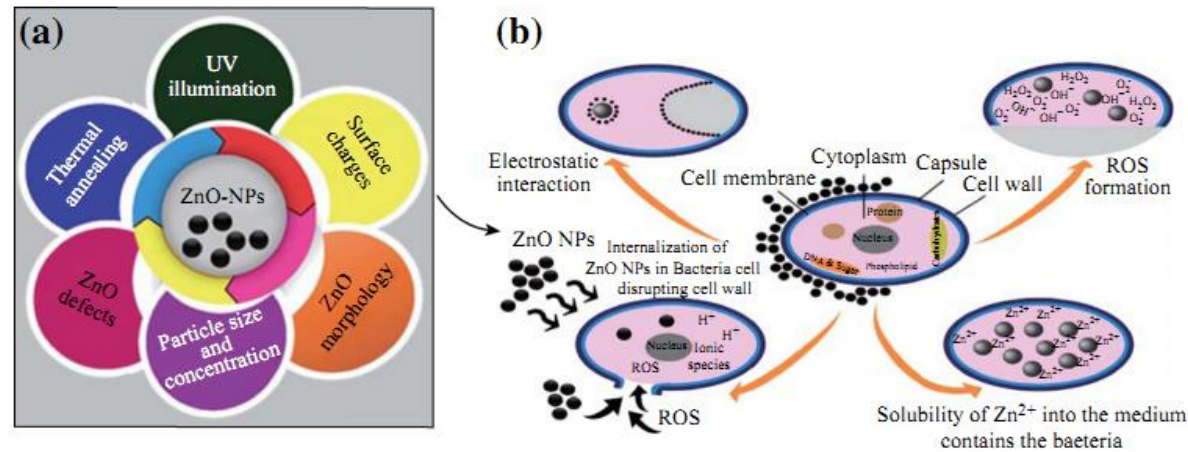

Fig. 6. Antibacterial activity of ZnO NP [72]. a) - important parameters of ZnO NP that affect the antibacterial reaction; b) - mechanisms of antibacterial activity of $\mathrm{ZnO} N P$ : formation of ROS, $\mathrm{Zn}^{2+}$ release, penetration of $\mathrm{ZnO}$ $\mathrm{NP}$ in bacteria and electrostatic interactions. 
inactivate organisms. $\mathrm{ZnO}$ nanoparticles in an aqueous solution under the influence of UV radiation have a phototoxic effect that can produce reactive oxygen species, such as superoxide ions $\left(\mathrm{O}_{2}{ }^{-}\right)$. They are extremely important for bioapplication. The formed ROS are able to penetrate into cells, thereby inhibiting or killing microorganisms. This process has given impetus to the use of $\mathrm{ZnO} \mathrm{NP}$ in bionanotechnology and in bionanomedicine for many antibacterial applications. The increase in $\mathrm{ZnO}$ bioactivity was considered as a result of the free radicals formed, as $\mathrm{ZnO}$ absorbs ultraviolet light [72].

Numerous studies consider the generation of ROS as the main cause of nanotoxicity [73]. Such reactive species are superoxide anion $\left({ }^{\circ} \mathrm{O}^{2-}\right)$, hydrogen peroxide $\left(\mathrm{H}_{2} \mathrm{O}_{2}\right)$ and hydroxide $\left(\mathrm{OH}^{-}\right)$. Their toxicity is the destruction of cellular components such as lipids, DNA and proteins due to their penetration into the cell membrane of bacteria.

ROS formation can be described as the interaction of electrons and holes in photocatalysis with water $\left(\mathrm{H}_{2} \mathrm{O}\right)$ where ${ }^{\circ} \mathrm{OH}$ and $\mathrm{H}^{+}$are produced. In addition, $\mathrm{O}_{2}$ molecules (suspended in a mixture of bacteria and $\mathrm{ZnO}$ ) give the anion of superoxide $\left({ }^{\circ} \mathrm{O}^{2-}\right)$, which reacts with $\mathrm{H}^{+}$ and forms $\mathrm{HO}_{2}^{\circ}$, then $\mathrm{HO}_{2}^{\circ}$ interacts with electrons, which leads to the appearance of ${ }^{\circ} \mathrm{HO}_{2}$, which combines with $\mathrm{H}^{+}$, giving molecules of hydrogen peroxide $\left(\mathrm{H}_{2} \mathrm{O}_{2}\right)$. Hydrogen peroxide is able to get into the membrane where it either damages or kills bacteria. The generation of $\mathrm{H}_{2} \mathrm{O}_{2}$ mainly depends on the surface of $\mathrm{ZnO}$ nanoparticles, there is a linear proportionality between the concentration of $\mathrm{H}_{2} \mathrm{O}_{2}$ formed in the $\mathrm{ZnO}$ suspension and the particle size of $\mathrm{ZnO}$ [74].

Superoxides and hydroxyl radicals cannot penetrate the membrane due to their negative charges. Thus, ROS are placed on the outer surface of bacteria, and $\mathrm{H}_{2} \mathrm{O}_{2}$ molecules, on the contrary, are able to pass through the cell wall of bacteria, subsequently leading to injury and destruction, and finally, initiating cell death. When $\mathrm{ZnO}$ nanoparticles kill or interact with the cell membrane, the particles are likely to remain strongly adsorbed on the surface of the remaining/killed bacteria, blocking additional antibacterial activity. Once the ZnO NP enter the growth medium, they will form peroxides, covering the entire surface of the dead bacteria. Therefore, this continuous release of peroxide leads to higher bactericidal efficiency.

We must also say about the effectiveness of morphology, which is expressed as the percentage of active faces of NP. The faces of $\mathrm{ZnO}$ with a high atomic density orientation (111) show higher antibacterial activity [75]. The face-dependent antibacterial activity of $\mathrm{ZnO}$ has been evaluated by several studies that have shown that $\mathrm{ZnO}$ nanostructures with different morphologies have different antibacterial activity. In this regard, the shape of $\mathrm{ZnO}$ nanostructures can affect their mechanism of penetration into the cell, for example, rods and wires penetrate into the cell walls of bacteria more easily than spherical $\mathrm{ZnO}$ nanoparticles [76].

At present, the antiviral properties of photocatalytic materials have been studied much less than antibacterial. But some studies have reported that $\mathrm{ZnO}$ nanoparticles are extremely effective against the ability of viruses to spread [77-79].

The procedure of virus infection mainly consists of attachment, penetration, replication, while antiviral functional nanoparticles are designed to inhibit viruses by blocking or suppressing some of the stages of virus activity.

The most direct way to suppress viruses is to inactivate it, and some of the nanostructures can interact with viruses, change the structure of the capsid protein, and then dramatically reduce virulence, which can be attributed to both physical and chemical mechanisms to reduce the number of active viruses. Most viral infections begin by attaching to host cells, usually by binding to the target acceptor protein. If the nanoparticles can effectively inhibit adhesion, the host cells will not be infected.

When a virus enters cell destruction of replication is another effective strategy for inhibiting the virus, which is usually achieved by suppressing the activities of certain enzymes that initially helped complete the replication of viral DNA or RNA. The main strategy is to slow down the budding of the virus and remove it from the host cells, and if functional nanoparticles prevent the virus from spreading, it significantly reduces virulence.

Ghaari et al. developed zinc oxide nanoparticles to inhibit the H1N1 influenza virus [80]. It has also been found that titanium dioxide nanoparticles $\mathrm{TiO}_{2}$ inactivate the H3N2 influenza virus by directly destroying viral particles [81]. Nanoparticles can also be used as antiviral drug carriers by self-assembly structures to prevent transmission of Zika virus [82].

In conclusion, we emphasize that all these developments have appeared in the recent years, which indicates the prospects for the applications of nanostructured materials based on $\mathrm{ZnO}$ for the antiviral and antibacterial applications.

\section{Conclusions}

It is shown that $\mathrm{ZnO}$ in nanoscale form is a potential photocatalytic material for photodegradation of persistent organic pollutants. Today, $\mathrm{ZnO}$ nanostructures of various forms, obtained by different methods, are actively investigated as prospective photocatalysts compared to $\mathrm{TiO}_{2}$ due to its low cost of production $(75 \%$ lower than $\mathrm{TiO}_{2}$ ), non-toxicity and the ability to absorb more of the solar spectrum.

There are different approaches to enhance the photocatalytic activity of $\mathrm{ZnO}$ nanostructures. It is shown that $\mathrm{ZnO}$ nanoparticles with specific surfaces showed the highest POP removal coefficient. From the above examples it was proved that the high efficiency of the photocatalytic reaction can be achieved by appropriate selection of the desired shape of the nanostructures, the method of synthesis, the appropriate photocatalytic system. Methods such as metal/non-metal doping, combination of $\mathrm{ZnO}$ with other materials, production of hybrid structures show the best results for the use of $\mathrm{ZnO}$-based nanostructures as an effective photocatalyst.

$\mathrm{ZnO}$ nanoparticles are extremely effective against bacteria and viruses and affect their ability to spread. They can be used to neutralize bacteria; detection of 
viruses, which leads to the production of various biosensors based on new functional nanoparticles; as high-potency inhibitors of viral spread.

To ensure more stable and better efficiency in the photodegradation of organic pollutants in a larger application, future research should look at overcoming the weaknesses of $\mathrm{ZnO}$ and the practical problems that still exist.

\section{Acknowledgements}

This work was partially supported by the research projects of the NAS of Ukraine "The development of photocatalytic nanocomposites for viruses inactivation in the air" and "Development of innovative photocatalytic nanostructured materials based on $\mathrm{ZnO}$ and $\mathrm{TiO}_{2}$ "”.

Baibara O.E. - Junior Research Fellow;

Radchenko M.V. - PhD (Physical and Mathematical Sciences), senior researcher;

Karpyna V.A. - PhD (Physical and Mathematical Sciences), senior researcher;

Ievtushenko A.I. - PhD (Physical and Mathematical Sciences), Senior Researcher, Head of Department.

[1] K.M. Lee, C.W. Lai, K.S. Ngai, J.C. Juan, Water Res. 88, 428 (2016); https://doi.org/10.1016/j.watres.2015.09.045.

[2] P. Chowdhary, A. Raj, R.N. Bharagava, Chemosphere 194, 229 (2018); https://doi.org/10.1016/j.chemosphere.2017.11.163.

[3] P. Franco, O. Sacco, I. De Marco, V. Vaiano, Catalysts. 346, 1 (2019); https://doi.org/10.3390/catal9040346.

[4] S.H. Khan, B. Pathak, Environmental Nanotechnology, Monitoring and Management 13, 100290 (2020); https://doi.org/10.1016/j.enmm.2020.1002.

[5] M.J. Hajipour, K.M. Fromm, A.A. Ashkarran, D.J.d. Aberasturi, I.R. de Larramendi, T. Rojo, V. Serpooshan, W.J. Parak, M. Mahmoudi, Trends Biotechnol. 30, 499 (2012); https://doi.org/10.1016/j.tibtech.2012.06.004.

[6] Cuicui Hu, Lu Lu, Yanjie Zhu, Rong Li, Yanjun Xing, Mater. Chem. Phys. 217, 182 (2018); https://doi.org/10.1016/j.matchemphys.2018.06.068.

[7] Z. Fan, J.G. Lu, J. Nanosci. Nanotechnol. 5, 1561 (2005); https://doi.org/10.1166/jnn.2005.182.

[8] Attarad Ali, Abdul-Rehman Phull and Muhammad Zia, Nanotechnology Reviews 7(5), 413 (2018); https://doi.org/10.1515/ntrev-2018-0067.

[9] T. Jin, D. Sun, Y. Su, H. Zhang, H.J. nSue, J Food Sci. $74, \quad 46 \quad$ (2009); https://10.1111/j.17503841.2008.01013.x.

[10] L. Zhang, Y. Jiang, Y. Ding, J Nanopart Res 9, 479 (2007); https://doi.org/10.1007/s11051-006-9150-1.

[11] R.B. Reed, D.A. Ladner, C.P. Higgins, P. Westerhoff, J.F. Ranville, Environ. Toxicol. Chem. 31, 93 (2012); https://doi.org/10.1002/etc.708.

[12] S. Malato, J. Blanco, A. Vidal, C. Richter, Appl Catal B Environ. 37, 1 (2002); https://doi.org/10.1016/S09263373(01)00315-0.

[13] Wang Kuo-Hua, Tsai Huan-Hung, Hsieh Yung-Hsu, Chemosphere 36, 2763 (1998); https://doi.org/10.1016/s0045-6535(97)10235-1.

[14] J-M. Herrmann, Catal Today. 53, 115 (1999); https://doi.org/10.1016/S0920-5861(99)00107-8.

[15] C.-O.O. Mauren, O.J. Nnaumeka, A.N. Basil, O.E. Emeka, International Letters of Chemistry, Physics and Astronomy 81, 16 (2019); https://doi.org/10.18052/www.scipress.com/ILCPA.81.18.

[16] D. Rajamanickam, M. Shanthi, Arab J Chem. 9, 1858 (2016); https://doi.org/10.1016/j.arabjc.2012.05.006.

[17] P. Banerjee, S. Chakrabarti, S. Maitra, B.K. Dutta, Ultrason Sonochem 19, 85 (2012); https://doi.org/10.1016/j.ultsonch.2011.05.007.

[18] F. Wang, X. Qin, Z. Guo, Y. Meng, L. Yang, Y. Ming, Ceram Int. 39, 8969 (2013); https://doi.org/10.1016/j.ceramint.2013.04.096.

[19] Y. Fang, Z. Li, S. Xu, D. Han, D. Lu, J Alloy Compd. 575, 359 (2013); https://doi.org/10.1016/j.jallcom.2013.05.183.

[20] S.K. Lim, S.-H. Hwang, S. Kim, H. Park, Sens Actuators B Chem. 160, 94 (2011).

[21] S. Jiao, K. Zhang, S. Bai, H. Li, S. Gao, H. Li, Electrochim Acta. 111, 64 (2013); http://dx.doi.org/10.1016/j.electacta.2013.08.050.

[22] D.Y. Jiang, J.X. Zhao, M. Zhao, Q.C. Liang, S. Gao, J.M. Qin, J. Alloy Compd. 532, 31 (2012); http://dx.doi.org/10.1016/j.jallcom.2012.03.114.

[23] X. Ma, J. Zhang, J. Lu, Z. Ye, Appl Surf Sci. 257, 1310 (2010); https://doi.org/10.1016/j.apsusc.2010.08.057.

[24] W. Ouyang, J. Zhu, Mater Lett. 62, 124 (2008); https://doi.org/10.1016/j.matlet.2007.12.051.

[25] N. Zhang, R. Yi, R. Shi, G. Gao, G. Chen, X. Liu, Mater Lett. 63, 35 (2009); https://doi.org/10.1016/j.matlet.2008.11.046.

[26] C-H. Lee, D-W. Kim, Thin Solid Films 546, 38 (2013); https://doi.org/10.1016/j.tsf.2013.05.029.

[27] P. Hu, N. Han, D. Zhang, J.C. Ho, Y. Chen, Sens Actuators B Chem. 169, 74 (2012); https://doi.org/10.1016/j.snb.2012.03.035.

[28] C. Wang, Z. Chen, H. Hu, D. Zhang, Phys B Condens Matter. 404, 4075 (2009).

[29] E.S. Jang, J-H. Won, S-J. Hwang, J-H. Choy, Adv Mater. 18, 3309 (2006); https://doi.org/10.1002/adma.200601455. 
A Review of the Some Aspects for the Development of $\mathrm{ZnO}$ Based Photocatalysts...

[30] X. Zhang, J. Qin, Y. Xue, P. Yu, B. Zhang, L. Wang, Sci Rep. 4, 4596 (2014); https://doi.org/10.1038/srep04596.

[31] S. Zavar, Arab J Chem. 10, 67 (2017); https://doi.org/10.1016/j.arabjc.2012.07.011.

[32] N.K. Hassan, M.R. Hashim, M. Bououdina, Ceram Int. 39, $7439 \quad$ (2013); https://doi.org/10.1016/j.ceramint.2013.02.088.

[33] D. Ju, H. Xu, J. Zhang, J. Guo, B. Cao, Sens Actuators B Chem. 201, 444 (2014); https://doi.org/10.1016/j.snb.2014.04.072.

[34] S. Yue, J. Lu, J. Zhang, Mater Chem Phys. 117, 657 (2009).

[35] Reza Mahdavi, S. Siamak Ashraf Talesh, Adv. Powder Technol. 28, 1418 (2017); https://doi.org/10.1016/j.apt.2017.03.014.

[36] M. Ahmed, E. Ahmed, Yuewei Zhang, N.R. Khalid, Jianfeng Xu, M. Ullah, Zhanglian Hong, Curr Appl Phys. 13, 697 (2013); https://doi.org/10.1016/j.cap.2012.11.008.

[37] Yumin Wang, Xia Zhang, Chao Hou, Nano-Structures \& Nano-Objects. 16, 250 (2018); https://doi.org/10.1016/j.nanoso.2018.07.001.

[38] Angelica Gonçalves Oliveira, Jessica de Lara Andrade, Maiara Camotti Montanha, Sandro Marcio Lima, Luis Humberto da Cunha Andrade, Ana Adelina Winkler Hechenleitner, Edgardo Alfonso Gomez Pineda, Daniela Martins Fernandes de Oliveira, J. Environ. Manage. 240, 485 (2019); https://doi.org/10.1016/j.jenvman.2019.03.124.

[39] Chun Li, Ruisheng Hu, Tingting Zhou, Haitao Wu, Kunpeng Song, Xiaoxia Liu, Ruida Wang, Mater. Lett. 124, 81 (2014); https://doi.org/10.1016/j.matlet.2014.03.056.

[40] Tio Mahardika, Nur Ajrina Putri, Anita Eka Putri, Vivi Fauzia, Liszulfah Roza, Iwan Sugihartono, Yuliati Herbani, Results Phys. 13, 102209 (2019); https://doi.org/10.1016/j.rinp.2019.102209.

[41] Yutong Liu, Qiuping Zhang, Ming Xu, Huan Yuan, Yu Chen, Jiaxi Zhang, Kaiyi Luo, Jingquan Zhang, Biao You, Appl. Surf. Sci. 476, 632 (2019); https://doi.org/10.1016/j.apsusc.2019.01.137.

[42] Xueli Li, Sisi He, Xuesheng Liu, Junsu Jin, Hong Meng, Ceram. Int. 45, 494 (2019); https://doi.org/10.1016/j.ceramint.2018.09.195.

[43] Qun Ma, Xiangzhou Lv, Yongqian Wang, Jieyu Chen, Opt. Mater. 60, 86 (2016); https://doi.org/10.1016/j.optmat.2016.07.014.

[44] M.N. Goswami, P.K. Mahapatra, Physica E. 104, 254 (2018); https://doi.org/10.1016/j.physe.2018.07.042.

[45] Nimisha N. Kumaran, K. Muraleedharan, J. Water Process Eng.17, 264 (2017); https://doi.org/10.1016/j.jwpe.2017.04.014.

[46] I. Neelakanta Reddy, Ch. Venkata Reddy, M. Sreedhar, Jaesool Shim, Migyung Cho, Dongseo Kim, Mater. Sci. Eng. B. 240, 33 (2019); https://doi.org/10.1016/j.mseb.2019.01.002.

[47] Numan Salah, A. Hameed, M. Aslam, Saeed S. Babkair, F.S. Bahabri, J. Environ. Manage. 177, 53 (2016); https://doi.org/10.1016/j.jenvman.2016.04.007.

[48] Jihui Lang, Jiaying Wang, Qi Zhang, Xiuyan Li, Qiang Han, Maobin Wei, Yingrui Sui, Dandan Wang, Jinghai Yang, Ceram. Int. 42, 14175 (2016); https://doi.org/10.1016/j.ceramint.2016.06.042.

[49] P. Visali, R. Bhuvaneswari, Optik. 202, 16706 (2019); https://doi.org/10.1016/j.ijleo.2019.163706.

[50] N. Zarei, M.A. Behnajady, Desalination and Water Treatment. 32, 1 (2015); https://doi.org/10.1080/19443994.2015.1083479.

[51] A. Samanta, M.N. Goswami, P.K. Mahapatra, Physica E: Low dimensional Systems and Nanostructures. 104, 87 (2018); https://doi.org/10.1016/j.physe.2018.07.042.

[52] C. Abed, C. Bouzidi, H. Elhouichet, B. Gelloz, M. Ferid, Applied Surface Science. 349, 855 (2015); https://doi.org/10.1016/j.apsusc.2015.05.078.

[53] T. Jia, W. Wang, F. Long, Z. Fu, H. Wang, Q. Zhang, J. Alloys Compd. 484, 410 (2009); https://doi.org/10.1016/j.jallcom.2009.04.153.

[54] N. Clament Sagaya Selvam, J. Judith Vijaya, L. John Kennedy, Journal of Colloid and Interface Science. 407, 215 (2013); https://doi.org/10.1016/j.jcis.2013.06.004.

[55] S. Anandan, M. Miyauchi, Electrochemistry 79, 842 (2011); 10.5796/electrochemistry.79.842.

[56] K. Qi, B. Cheng, J. Yu, W. Ho, J. Alloys Compd. 727, 792 (2017); https://doi.org/10.1016/j.jallcom.2017.08.142.

[57] A. Hui, J. Ma, J. Liu, Y. Bao, J. Zhang, J. Alloys Compd. 696, 639 (2017); https://doi.org/10.1016/j.jallcom.2016.10.319.

[58] X. Li, Z. Hu, J. Liu, D. Li, X. Zhang, J. Chen, J. Fang, Appl. Catal. B 195, 29 (2016); https://doi.org/10.1016/j.apcatb.2016.05.002.

[59] H. Benhebal, M. Chaib, C. Malengreaux, S.D. Lambert, A. Leonard, M. Crine, B. Heinrichs, J. Taiwan Inst. Chem. Eng. 45, 249 (2014); https://doi.org/10.1016/j.jtice.2013.04.003.

[60] J. Lv, F. Shang, G. Pan, F. Wang, Z. Zhou, C. Liu, W. Gong, Z. Zi, X. Chen, G. He, J. Mater. Sci. Mater. Electron. 25, 882 (2014); https://doi.org/10.1007/s10854-013-1660-x.

[61] H. Zhao, F. Tian, R. Wang, R. Chen, Adv. Sci. Eng. 3, 3 (2014); https://doi.org/10.1166/rase.2014.1050.

[62] Y. Zong, Z. Li, X. Wang, J. Ma, Y. Men, Ceram. Int. 40, 10375 (2014); 10.1016/j.ceramint.2014.02.123.

[63] R. Raji, K.G. Gopchandran, Journal of Hazardous Materials. 368, 345 (2019); https://doi.org/10.1016/j.jhazmat.2019.01.052. 
[64] X. Bian, K. Hong, X. Ge, R. Song, L. Liu, J. Phys. Chem. C. 119, 1700 (2015); https://doi.org/10.1021/jp5108312.

[65] C. Borgohaina, K.K. Senapatia, K.C. Sarmab, P. Prodeep, J. Mol. Catal. A. Chem. 363, 495 (2012); https://doi.org/10.1016/j.molcata.2012.07.032.

[66] R.B. Reed, D.A. Ladner, C.P. Higgins, P. Westerhoff, J.F. Ranville, Environ. Toxicol. Chem. 31, 93 (2012); https://doi.org/10.1002/etc.708.

[67] Y. Zhang, R.T. Nayak, H. Hong, W. Cai, Curr. Mol. Med. 13, 1633 (2013).

[68] R. Brayner, R. Ferrari-Iliou, N. Brivois, S. Djediat, M.F. Benedetti, F. Fie 'vet, Nano Lett. 6, 866 (2006); https://doi.org/10.1021/n1052326h.

[69] K. Kasemets, A. Ivask, H.-C. Dubourguier, A. Kahru, Toxicol. In Vitro. 23, 1116 (2009); https://doi.org/10.1016/j.tiv.2009.05.015.

[70] R. Jalal, E.K. Goharshadi, M. Abareshi, M. Moosavi, A. Yousefi, P. Nancarrow, Mater. Chem. Phys. 121, 198 (2010); https://doi.org/10.1016/j.matchemphys.2010.01.020.

[71] A. Lipovsky, Y. Nitzan, A. Gedanken, R. Lubart, Nanotechnology 22, 105101 (2011); https://doi.org/10.1088/0957-4484/22/10/105101.

[72] Amna Sirelkhatim, Shahrom Mahmud, Azman Seeni, Noor Haida Mohamad Kaus, Ling Chuo Ann, Siti Khadijah Mohd Bakhori, Habsah Hasan \& Dasmawati Mohamad, Nano-Micro Lett. 7, 219 (2015); https://doi.org/10.1007/s40820-015-0040-X.

[73] T. Xia, M. Kovochich, M. Liong, L. Ma“dler, B. Gilbert, H. Shi, J.I. Yeh, J.I. Zink, A.E. Nel, ACS Nano. 2 , 2121 (2008); https://doi.org/10.1021/nn800511k.

[74] J. Sawai, E. Kawada, F. Kanou, H. Igarashi, A. Hashimoto, T. Kokugan, M. Shimizu, J. Chem. Eng. Jpn. 29, 627 (1996); https://doi.org/10.1252/jcej.29.627.

[75] S. Pal, Y.K. Tak, J.M. Song, Appl. Environ. Microbiol. 73, 1712 (2007); https://doi.org/10.1128/AEM.02218$\underline{06}$.

[76] H. Yang, C. Liu, D. Yang, H. Zhang, Z. Xi, J. Appl. Toxicol. 29, 69 (2009); https://doi.org/10.1002/jat.1385.

[77] E. Russo, N. Gaglianone, S. Baldassari, B. Parodi, S. Cafaggi, C. Zibana, M. Donalisio, V. Cagno, D. Lembo, G. Caviglioli, Colloids Surf. B Biointerfaces 118, 117 (2014); https://doi.org/10.1016/j.colsurfb.2014.03.037.

[78] S. Chaudhuri, J.A. Symons, J. Deval, Antivir. Res. 155, 76 (2018); https://doi.org/10.1016/j.antiviral.2018.05.005.

[79] H.F. Hang, H.R. Peng, H.Y. Song, Z.T. Qi, X.H. Miao, W.S. Xu, J. Virol. Meth. 222, 150 (2015); https://doi.org/10.1016/j.jviromet.2015.06.010.

[80] H. Ghaari, A. Tavakoli, A. Moradi, A. Tabarraei, F. Bokharaei-Salim, M. Zahmatkeshan, M. Farahmand, D. Javanmard, S.J. Kiani, M. Esghaei, V. Pirhajati-Mahabadi, S.H. Monavari, A. Ataei-Pirkooh, J. Biomed. Sci. 26, 1 (2019); https://doi.org/10.1186/s12929-019-0563-4.

[81] N.A. Mazurkova, Y.E. Spitsyna, N.V. Shikina, Z.R. Ismagilov, S.N. Zagrebel'nyi, E.I. Ryabchikova, Nanotechnol. Russ. 5, 417 (2010); https://doi.org/10.1134/S1995078010050174.

[82] B. Surnar, M.Z. Kamran, A.S. Shah, U. Basu, N. Kolishetti, S. Deo, D.T. Jayaweera, S. Daunert, S. Dhar, ACS Nano. 13, 11034 (2019); https://doi.org/10.1021/acsnano.9b02807.

\author{
О.Є. Байбара, Радченко М.В., В.А. Карпина, А.І. Євтушенко
}

\title{
Огляд деяких аспектів розробки фотокаталізаторів на основі ZnO для різноманітних застосувань
}

Інститут проблем матеріалознавства ім. І.М. Францевича НАН України, Київ, Україна, baibaraoleksii@gmail.com

\begin{abstract}
На сьогоднішній день однією з найважливішими проблем для людства є забруднення навколишнього середовища різними органічними сполуками, які погіршують здоров'я населення. Найбільш небезпечними забруднювачами при цьому є складні з'єднання, що не піддаються деградації в природних умовах. Одним із способів вирішення проблеми забруднення $є$ використання фотокаталізу для деградації шкідливих сполук. Наноструктури на основі оксиду цинку виявляють привабливі фотокаталітичні та антибактеріальні властивості завдяки підвищеній реакційній здатності поверхні наночастинок, що дозволяє ефективно розкладати органічні забруднювачі. В даному огляді розглядаються різні методи посилення фотоефективності наноструктур ZnO. Показано, що наночастинки ZnO зі специфічними поверхнями (сферичні, нанодроти, наноквіти) володіють і високим коефіцієнтом видалення різноманітних забруднювачів. Розглянуто такі методи покращення фотокаталітичних властивостей ZnO як зміна ширини забороненої зони, легування металом/неметалом, поєднання ZnO з іншими матеріалами, формування гібридних структур.

Ключові слова: оксид цинку, фотокаталіз, фотодеградація, наноструктури, антибактеріальні властивості.
\end{abstract}

